ROCZNIKI KULTUROZNAWCZE

Tom X, numer $3-2019$

DOI: http://dx.doi.org/10.18290/rkult.2019.10.3-4

\title{
LUXURIA, GRZECH I KARA. \\ PRZYCZYNEK DO BADAŃ IKONOGRAFICZNYCH OŁTARZA \\ SĄDU OSTATECZNEGO JHERONIMUSA BOSCHA (I JEGO WARSZTATU) Z AKADEMIE DER BILDENDEN KÜNSTE W WIEDNIU. CZĘŚĆ I
}

\section{WPROWADZENIE, CEL BADAWCZY}

Do 2016 r., kiedy to ukazał się Catalogue Raisonné dzieł Jheronimusa Boscha (ok. 1450-1516), sygnowany nazwiskami ośmiu badaczy z Bosch Research and Conservation Project (BRCP) ${ }^{1}$, Ottarz Sadu Ostatecznego z Galerii Malarstwa Akademii Sztuk Pięknych w Wiedniu (GG-579-581) był powszechnie uważany za niekwestionowane dzieło w oeuvre malarza z 's-Hertogenbosch ${ }^{2}$. Członkowie BRCP - niestety nie uzyskali zgody od władz Akademii Sztuk Pięknych, aby poddać tryptyk badaniom technicznym - opierając się w głównej mierze na publikacjach Stefana Fischera ${ }^{3}$ oraz Renate Trnek ${ }^{4}$,

Dr GRZEGORz KuBIES - muzykolog i historyk sztuki, członek Związku Kompozytorów Polskich (Sekcja Muzykologów); adres do korespondencji: e-mail: kubies1971@interia.pl

${ }^{1}$ Zespół BRCP prowadził badania w latach 2010-2016. Zob. http://boschproject.org (dostęp: 01.08.2019).

${ }^{2}$ Zob. m.in. Roger H. MARiJnissen, Peter RuyfFelaere, Hieronymus Bosch. Das vollständige Werk (Antwerpen: Mercatorfonds, 1999), 214-233; Jos KoldeweiJ, Paul VAndenBroeck, Bernard VERMET, Hieronymus Bosch. The Complete Paintings and Drawings (Rotterdam, Ghent: NAi Publishers, Ludion, 2001), 176-182; Larry SILVER, Hieronymus Bosch (New York: Abbeville Press, 2006), 337-348; Stefan Fischer, Hieronymus Bosch. The Complete Works (Köln: Taschen, 2013), 154-175, 250-251. Taką samą linię interpretacyjną przyjmuje też Gary SchwARTz, Jheronimus Bosch. The Road to Heaven and Hell (New York, London: Overlook Duckworth, 2016), 160-164.

${ }^{3}$ FISCHER, Hieronymus Bosch, 154-175.

${ }^{4}$ Renate TrNeK, „Patron Lost. First Insights into the Underdrawings of the Last Judgement Triptych by Jheronimus Bosch in Vienna", w Frances KemP, Jos KoldeweiJ, Hannah Gooiker, red., Jheronimus Bosch. His Patrons and his Public. 3rd International Jheronimus Bosch Conference, September 16-18, 2012 Jheronimus Bosch Art Center, 's-Hertogenbosch The Netherlands ('s-Hertogenbosch: Jheronimus Bosch Art Center, 2014), 264-279. 
uznają Ottarz wiedeński, który datują na lata ok. 1500-1505, za dzieło Boscha i jego warsztatu. Choć wskazują na wyraźne różnice stylistyczne w podrysowaniu (jako rysunki autorskie malarza interpretowane są tylko te na odwrociach skrzydeł) i w warstwie malarskiej trzech tablic, to niemniej przyznają jednak, że ikonografia Ottarza jako całość oraz wiele pojedynczych motywów i figur odzwierciedla świat wyobraźni Boscha. Badacze z BRCP, kwestionując często przytaczaną w literaturze przedmiotu hipotezę, jakoby Ottarz powstał na zamówienie księcia Burgundii Filipa I Pięknego $(1478-1506)^{5}$, wysuwają przypuszczenie, że zleceniodawcą mógł być Hippolyte de Berthoz (zm. 1503), w latach 1472-1499 wysokiej rangi urzędnik na dworze burgundzkim ${ }^{6}$. W roku 2017, a więc już po publikacji Catalogue Raisonné, nowym dyrektorem Galerii Malarstwa Akademii Sztuk Pięknych w Wiedniu została Julia M. Nauhaus, która wyraziła zgodę na badania techniczne tryptyku. Rezultatem współpracy członków BRCP oraz zespołu z Uniwersytetu w Antwerpii jest artykuł, w którym badacze dowodzą, że zleceniodawcą dzieła był faktycznie Hippolyte de Berthoz ${ }^{7}$. Pracownicy Galerii Malarstwa wiedeńskiej Akademii Sztuk Pięknych uznają Ottarz za autentyczne dzieło Boscha i szacują czas jego realizacji

\footnotetext{
${ }^{5}$ Podstawę ku krytycznej ocenie owej hipotezy stanowią nie tylko rozmiary tryptyku z Wiednia $(164 \times 247 \mathrm{~cm})$, znacząco odbiegające od rozmiarów podanych w cytowanym poniżej zleceniu (,neuf pietz de hault et onze pietz de long" $-9 \times 11$ stóp, czyli ok. $249 \times 304 \mathrm{~cm}$ ), ale i brak dokumentów poświadczających całkowitą zapłatę za Ottarz czy też dostarczenie ukończonego dzieła. Treść książęcego zamówienia z 1504 r. brzmi następująco: „Septembre l'an xvc quatre A Jeronimus van Aeken dit Bosch paintre de[meurant] au Bois le Duc la somme de trente six livres dudict pris en prest et paiement à bon compte sur ce qu'il lui povoit et pourroit estre deu sur ung grant tableau de paincture de neuf pietz de hault et onze pietz de long, où doit estre le Jugement de Dieu assavoir paradis et infer que icellui S[eigneur] lui avoit ordonné faire pour son tres noble plaisir. Pour ce icy par sa quictancy rend[ue] ladicte somme de xxxvj 1[ivres]" (Lille, Archives départementales du Nord, B 2185, fol. 230v). Cyt. za Godfried C.M. van DıJCK, Op zoek naar Jheronimus van Aken alias Bosch. De feiten, familie, vrienden en opdrachtgevers, ca. $1400-c a .1635$ (Zaltbommel: Europese Bibliotheek, 2001), 91.

${ }^{6}$ Matthijs Ilsink, Jos Koldeweid, Ron Spronk, Luuk Hoogstede, Robert G. Erdmann, Rik Klein Gotink, Hanneke NAP, Daan Veldhuizen, Hieronymus Bosch, Painter and Draughtsman. Catalogue Raisonné (Brussels: Mercatorfonds, 2016), 290-307. Badacze interpretują postać wykonaną en grisaille na prawym skrzydle Ottarza nie jako św. Bawona, lecz św. Hipolita, czyli patrona domniemanego (zob. tekst główny) donatora tryptyku; na lewym skrzydle został ukazany św. Jakub. Warto zauważyć, że ten ostatni oraz św. Bawon byli czczeni odpowiednio w Hiszpanii i Flandrii. Łączenie zamówienia na wykonanie Ottarza Sąu Ostatecznego z Filipem I Pięknym, ma związek z faktem, że był on władcą państwa burgundzkiego, do którego przynależała Flandria, a poprzez małżeństwo zawarte w roku 1496 z Joanną Kastylijską (1479-1555) od 1505 r. był także iure uxoris królem Kastylii.

7 Jos Koldeweis, Luuk Hoogstede, Matthijs Ilsink [i in.], „The patron of Hieronymus Bosch's 'Last Judgment' triptych in Vienna”, The Burlington Magazine 160/1379(2018): 106-111.
} 
na lata $1504-1508^{8}$. Podobną opinię wyraża międzynarodowa grupa historyków sztuki w krótkiej publikacji wydanej w Wiedniu, w roku pięćsetnej rocznicy śmierci malarza9.

Oltarz Sądu Ostatecznego (część środkowa: 164×127 cm, skrzydła: 164×60 cm) z Wiednia (il. 1) stanowi przykład reinterpretacji ikonografii tematu stosunkowo precyzyjnie określonego przez tradycję ${ }^{10}$. Identyfikację tryptyku jako przedstawienie Sądu Ostatecznego umożliwia obecność kilku motywów/figur w najwyższej strefie tablicy środkowej; są to: Chrystus zasiadający na podwójnym łuku tęczy, dwie grupy apostołów, Maria, św. Jan Chrzciciel oraz aniołowie fanfarzyści (zob. Mt 24,29-31; 25,31-46). Lewe skrzydło, w najwyższej strefie przedstawia upadek zbuntowanych aniołów (zob. Iz 14,12-15), a poniżej trzy epizody z Księgi Rodzaju: stworzenie Ewy (Rdz 2,21-22), nieposłuszeństwo pierwszych ludzi wobec Boga i wygnanie z raju ( $\operatorname{Rdz} 2,16$ 17; 3,1-24). Szeroka panorama rozmaitych kar piekielnych, wybitnie fizycznych w swej naturze ${ }^{11}$, ukazana w części środkowej i na prawym skrzydle tryptyku pozostaje $\mathrm{w}$ związku $\mathrm{z}$ przedstawioną na lewym skrzydle teologią

\footnotetext{
${ }^{8}$ Zob. http://www.akademiegalerie.at (dostęp: 10.07.2018). Jak dotąd, nie zostały opublikowane finalne wyniki rozpoczętych w 2011 r. badań technicznych i ikonograficznych Ottarza Boscha, prowadzonych przez zespół kierowany przez Renate Trnek. Jedyną publikacją Trnek powiązaną z projektem FWF jest ta wymieniona w przyp. 4. Zob. https://www.akbild.ac.at/Portal/kunstforschung/projekte/forschungsprojekte/2015 (dostęp: 10.07.2018). Na temat ostatecznego raportu zob. Maria D. Colagrande, Manfred SChreINER, 'Report of the FWF-project P23848-G2' (Vienna: Institute of Science and Technology in Art, Academy of Fine Arts, 2014).

${ }^{9}$ Nils Büttner, Julia M. Nauhaus, Erwin Pokorny, Larry Silver, Hieronymus Bosch in the Academy of Fine Arts Vienna (Vienna: Bibliothek der Provinz, 2017); książka została wydana w języku niemieckim w $2016 \mathrm{r}$.

${ }^{10}$ Zob. Beat BrenK, „Weltgericht”, w Engelbert KiRschBAum, red., Lexikon der Christlichen Ikonographie, t. 4 (Rom-Freiburg-Basel-Wien: Gerd Mohn, 1972), 513-523; Yves Christe, „Giudizio Universale”, w Angiola M. RomaninI, red., Enciclopedia dell'Arte Medievale, t. 6 (Roma: Istituto della Enciclopedia Italiana, 1995), 791-805; IDEM, Jugements derniers (Chantilly: Zodiaque, 2000). Zob. też Bernhard RIDDERBos, „Objects and Questions”, w Bernhard RIDDERBos, Anne van Buren, Henk van Veen, red., Early Netherlandish Painting. Rediscovery, Reception, and Research (Amsterdam: Amsterdam University Press, 2005), 31-36, 78-86. Ilustracje dzieł Boscha i jego pracowni w wysokiej rozdzielczości: http://boschproject.org/\#/artworks (dostęp: 01.08. 2019).

${ }^{11}$ Zob. Larry SiLver, „Crímenes y castigos. Los Infiernos del Bosco”, w Pilar Silva Maroto, red., El Bosco. La exposición del V Centenario (Madrid: Museo Nacional del Prado, 2016), $115-$ 133. Na temat tortur i przemocy w literaturze średniowiecznej zob. Larissa TRACY, Torture and Brutality in Medieval Literature. Negotiations of National Identity (Cambridge: D.S. Brewer, 2012). Zob. też Albrecht Classen, Connie Scarborough, red., Crime and Punishment in the Middle Ages and Early Modern Age. Mental-Historical Investigations of Basic Human Problems and Social Responses (Berlin-Boston: Walter de Gruyter, 2012); Faustine HARANG, La Torture au Moyen Âge, XIVe-XVe siècles (Paris: Presses Universitaires de France, 2017).
} 
$z^{12}$. Jego wtargnięcie w świat ziemski (pochodzi ono z rzeczywistości pozaempirycznej!) doprowadza do niemal totalnej zagłady ludzkości. A zbawienia, jak unaocznił malarz w lewym górnym rogu tablicy centralnej, gdzie w stronę światła aniołowie unoszą dusze ludzkie, doświadczą nieliczni (zob. Mt 22,14).

Reminiscencje oraz aluzje do grzechów nieczystości (luxuria) uobecniają się w Ottarzu wiedeńskim wielokrotnie ${ }^{13}$. Choć w kilku scenach pojawiają się instrumenty muzyczne, często w sztuce łączone z miłością, nie wyłączając erotycznych $i$ seksualnych odniesien ${ }^{14}$, to $\mathrm{w}$ literaturze przedmiotu aspekty muzyczne są często marginalizowane lub wręcz pomijane ${ }^{15}$. Głównym celem niniejszego artykułu, oprócz profilowanej muzykologicznie analizy ikonograficznej owych kilku scen, jest próba dotarcia do źródeł ideowych powiązania w wizji zaświatów dwóch elementów: kar odpowiadających jednemu z grzechów głównych i muzyki. Zasadniczy horyzont badawczy wyznaczają źródła ikonograficzne oraz literackie. $Z$ racji podejmowanej problematyki, w artykule należne miejsce znalazła refleksja teologiczna z odniesieniami do biblijnej logosfery.

\section{NIECZYSTOŚĆ W BIBLII I NAUCE MORALNEJ KOŚCIOŁA}

Zgodnie z nauczaniem nowotestamentowym „Z serca bowiem pochodzą złe myśli, zabójstwa, cudzołóstwa, czyny nierządne, kradzieże, fałszywe świadectwa, przekleństwa. To właśnie czyni człowieka nieczystym” (Mt 15, 19-20; zob. Mk 7,20-23) ${ }^{16}$. Choć przekaz całej perykopy (Mt 15,10-20) jest łatwo uchwytny, to $\mathrm{z}$ nieczystością jako taką zazwyczaj łączona jest

${ }^{12}$ Zob. Larry SiLVER, „Jheronimus Bosch and the Issue of Origins”, Journal of Historians of Netherlandish Art 1/1 (Summer 2009); https://jhna.org (dostęp: 12.07.2019).

${ }^{13}$ Zob. Dirk BAX, Hieronymus Bosch and Lucas Cranach. Two Last Judgement Triptychs. Description and exposition (Amsterdam: North-Holland Publishing Company, 1983), 75-284 i 443 (indeks: Luxuria [unchastity]). Monografia Dirka Baxa, stanowiąca obowiązkową pozycję bibliograficzną w studiach nad malarstwem Boscha, z którą można, a czasami należy polemizować, jest najobszerniejszym opracowaniem poświęconym ikonografii Ottarza z Wiednia.

${ }^{14}$ Zob. Yona PINSON, „Music”, w Helene E. RoBERTS, red., Encyclopedia of Comparative Iconography. Themes Depicted in Works of Art, t. 2 (Chicago, London: Fitzroy Dearborn Publishers, 1998), 634-636.

${ }^{15}$ Nieco więcej uwagi scenom muzycznym w Ottarzu z Wiednia poświęcili Albert P. de Mirimonde i Reinhold Hammerstein; Albert P. de MiRIMONDE, „Le symbolisme musical chez Jérôme Bosch", Gazette des Beaux-Arts 77(1971): 37-38; Reinhold HAMmERsteIn, Diabolus in musica. Studien zur Ikonographie der Musik im Mittelalter (Bern: Francke, 1974), 98-100.

${ }^{16}$ Tekst Biblii w języku polskim za Biblia Tysiąclecia (Poznań: Pallottinum, 2006). 
nieczystość w sferze seksualnej ${ }^{17}$. Wbrew temu, czego dowiadujemy się z Ewangelii wg św. Mateusza oraz św. Marka, św. Paweł za źródło nieczystości uznał ciało:

Jest zaś rzeczą wiadomą, jakie uczynki rodzą się z ciała: nierząd, nieczystość, wyuzdanie, bałwochwalstwo, czary, nienawiść, spory, zawiść, gniewy, pogoń za zaszczytami, niezgoda, rozłamy, zazdrość, pijaństwo, hulanki i tym podobne (Ga 5,19-21).

O ile popęd płciowy jest powszechnym faktem biologicznym, o tyle seksualność w każdym społeczeństwie podlega determinacji kulturowej. „Seks jako zjawisko społeczne - pisze Ruth Mazo Karras - stanowi szczególnie skomplikowane zagadnienie, bowiem wiąże się z kwestiami moralności religijnej, porządku społecznego, relacji między płciami oraz duszy pojedynczego człowieka" ${ }^{18}$. W nauce moralnej Kościoła pewne przejawy życia seksualnego, takie jak cudzołóstwo, konkubinat, rozpusta, nierząd, stosunki contra naturam traktowane są jako nieczyste, a co za tym idzie - grzeszne ${ }^{19}$. Konsekwencją złych czynów obdarzonych wolną wolą ludzi jest wieczne potępienie. Św. Paweł przestrzegał:

Nie łudźcie się! Ani rozpustnicy, ani bałwochwalcy, ani cudzołożnicy, ani rozwiąźli, ani mężczyźni współżyjący ze sobą, ani złodzieje, ani chciwi, ani pijacy, ani oszczercy, ani zdziercy nie odziedziczą królestwa Bożego (1 Kor 6,9-10).

W świetle średniowiecznej etyki chrześcijańskiej jako nieczyste uważane były też rozmaite formy zachowania sprzyjające czy wręcz prowadzące do pozamałżeńskiej (a nawet małżeńskiej nieprokreacyjnej) aktywności seksualnej. Można tu wymienić m.in. pożądliwe myśli, zalotne spojrzenia, zmysłowy taniec czy pieśni o miłości cielesnej ${ }^{20}$. Tradycja nauczania na temat grzechów głównych, do których zalicza się nieczystość, sięga okresu patrystycznego.

${ }^{17}$ Zob. też Wj 20,14.17; Mt 5,27-28; 15,10-20; Mk 7,14-23; 1 Kor 6,9-10.12-20; Ga 5,19-21; Ef 5,3-7; Kol 3,5-6; 1 Tes 4,3-7; Hbr 13,4.

${ }^{18}$ Ruth Mazo KARRAS, Seksualność w średniowiecznej Europie, thum. Arkadiusz Bugaj (Warszawa: PIW, 2012), 13.

${ }^{19}$ Zob. James A. Brundage, Law, Sex, and Christian Society in Medieval Europe (Chicago, London: University of Chicago Press, 1987; repr. 1990), 487-550; rozważania autora na powyższych stronach obejmują okres 1348-1517. Zob. też. Vern L. Bullough, James A. BRUNDAGE, red., Sexual Practices and the Medieval Church (Buffalo NY: Prometheus Books, 1982); IDEM, red., Handbook of Medieval Sexuality (New York, Abingdon OX: Routledge, 1996; repr. 2010).

${ }^{20}$ Zob. przykłady niewłaściwego zachowania, jakie podaje Johann Herolt (ok. 1386-1468) z Norymbergii. Jego pisma kaznodziejskie i homiletyczne krążące w Europie w rękopisach i inkunabułach cieszyły się dużą popularnością. Zob. Ian D.K. Siggins, A Harvest of Medieval Preaching. The Sermon Books of Johann Herolt, OP (Discipulus) (Bloomington IN: Xlibris Corporation, 2009), 70-73. 
Podział na siedem grzechów głównych, a dokładnie na siedem wad głównych (septem principalia vitia), dokonany przez Grzegorza Wielkiego (ok. 540604) w dziele Moralia. Komentarz do Księgi Hioba (31,45.87), został po pewnych modyfikacjach zaakceptowany w teologii średniowiecznej i przetrwał w nauczaniu Kościoła do czasów nam współczesnych ${ }^{21}$.

\section{NIECZYSTOŚĆ W MALARSTWIE BOSCHA}

Naturalnym punktem wyjścia w prezentowanych tu rozważaniach jest malarstwo Boscha. Zobrazowany w trzech dziełach grzech nieczystości, a wręcz wyeksponowany w madryckim Wozie z sianem, świadczy o wadze, jaką przypisywał mu autor, a być może i sami zleceniodawcy. Oto lista dzieł, w której przyjęto datację dzieł malarza zaproponowaną przez badaczy z BRCP: lewe skrzydło Tryptyku Wędrowca: Statek głupców/ Alegoria Obżarstwa, Pijaństwa i Rozpusty (Paryż, Musée du Louvre/ New Haven, Yale University Art Gallery, ok. 1500-1510)22 (il. 2-3), część środkowa tryptyku Wóz z sianem (Madryt, Museo Nacional del Prado, 1510-1516) ${ }^{23}$ (i1. 4), tablica Siedem Grzechów Głównych i Cztery Rzeczy Ostateczne (Madryt, Museo Nacional del Prado, ok. 1510-1520) $)^{24}$ (il. 5).

${ }^{21}$ Wykaz grzechów głównych zob. Katechizm Kościoła Katolickiego (Poznań: Pallottinum, 1994), 434-435 (nr 1866). W ujęciu Grzegorza Wielkiego siedem wad głównych obejmuje: inanis gloriae (próżna chwała), invidia (zazdrość), ira (gniew/ złość), tristitia (smutek), avaritia (chciwość), ventris ingluvies (obżarstwo/ łakomstwo), luxuria (nieczystość) (Moralia 31,45.87). W późnym średniowieczu popularny był także inny wykaz, tzw. SALIGIA (akronim ten został utworzony od pierwszych liter nazw każdego grzechu w języku łacińskim) mający następującą postać: superbia (pycha), avaritia (chciwość), luxuria (nieczystość), ira (gniew), gula (obżarstwo), invidia (zazdrość), acedia (lenistwo). Zob. Carla CASAgrande, Silvana VeCCHIO, I sette vizi capitali. Storia dei peccati nel Medioevo (Torino: Einaudi, 2000); Richard NEwHAUSER, red., In the Garden of Evil. The Vices and Culture in the Middle Ages (Toronto: Pontifical Institute of Mediaeval Studies, 2005).

${ }^{22}$ Ilsink, KoldeweiJ, Spronk [i in.], Hieronymus Bosch, 316-335. Strona internetowa muzeum w New Haven podaje, że środkową część tryptyku tworzyła najprawdopodobniej tablica przedstawiająca pięć grzechów głównych, mianowicie pychę, zazdrość, nieczystość, złość i lenistwo. Dwa pozostałe grzechy, tzn. obżarstwo i chciwość, widnieją odpowiednio na skrzydłach z Paryża/ New Haven i Waszyngtonu (Śmierć bogacza, National Gallery of Art); http://artgallery.yale.edu (dostęp: 14.07.2018).

${ }^{23}$ Ilsink, Koldewei, Spronk [i in.], Hieronymus Bosch, 336-355.

${ }^{24}$ Obraz z Prado uważany jest przez badaczy z BRCP za dzieło warsztatu Boscha lub jego naśladowcy, Ilsink, KoldeweiJ, SPRONK [i in.], Hieronymus Bosch, 468-475. Autorstwa Boscha nie kwestionuje Pilar Silva Maroto z Museo Nacional del Prado, która ponadto twierdzi, że obraz został namalowany w latach ok. 1505-1510; zob. Silva MARoto, red., El Bosco, 302-312. 
W Statku głupców nieczystość uosabiają podróżujący w łodzi członkowie dwóch zakonów: klaryska lub beginka i franciszkanin śpiewający do akompaniamentu lutni ${ }^{25}$. Tuż obok nich na desce leży talerz z wiśniami wykazującymi konotacje erotyczne. Pośród pasażerów łodzi oddających się przyjemnościom cielesnym znajduje się błazen, dobitnie wskazujący na głupotę owych ludzi. W Alegorii Obżarstwa, Pijaństwa i Rozpusty grzechy nieczystej miłości przywołuje para pijąca wino w namiocie, zaś pozostałe osoby, wraz z mężczyzną siedzącym na beczce i grającym na lituusie pozostają w związku z tytułowym grzechem nieumiarkowania $\mathrm{w}$ jedzeniu i piciu. W tryptyku madryckim jako przedstawienie nieczystości cielesnej interpretowana jest scena na szczycie wozu z sianem na tablicy środkowej ${ }^{26}$. Parze osób w zaroślach, ukazanej w zmysłowym uścisku, towarzyszą lutnista oraz duet wokalny. Scenę zamyka po lewej stronie anioł zwracający się w modlitwie do Chrystusa, a po prawej stronie demon przyłączający się do zespołu grą na aerofonie tworzącym organiczną część jego nosa. Grzechy nieczystości z tablicy Siedem Grzechów Głównych $i$ Cztery Rzeczy Ostateczne, wytworu warsztatu/ naśladowcy Boscha, personifikują pary wywodzące się z wyższych klas społecznych. Dwie osoby siedzące u wejścia do namiotu piją wino ze wspólnego naczynia, zaś stojący mężczyzna i kobieta w głębi namiotu oddają się flirtowi ${ }^{27}$. W kierunku stołu z owocami (wiśnie i pomarańcza) i stojącego obok dzbana na wino kieruje się na czworakach błazen. Mężczyzna stojący z tyłu za błaznem unosi w górę trzymaną oburącz dużą drewnianą łyżkę z zamiarem uderzenia go w pośladki. Motyw ten wywodzący się prawdopodobnie z niderlandzkiego przysłowia

${ }^{25}$ Zob. Walter S. GiBson, Hieronymus Bosch (London: Thames and Hudson, 1973; repr. 2001), 40-44; Erik LARSEN, Bosch. The Complete Paintings by the Visionary Master (New York: Smithmark, 1998), 139; FisCHER, Hieronymus Bosch, 191-192. Zob. też Laurinda DiXON, Hieronymus Bosch (New York: Phaidon, 2003; repr. 2006), 76. Badacze z BRCP dostrzegają w osobach duchownych aluzję do nieprzyzwoitości; ILSINK, KoldeweIJ, SPRonk [i in.], Hieronymus Bosch, 328. Friso Lammertse, autor opisu dzieła w katalogu z Prado, zachowanie zakonnicy i zakonnika określa jako zabawę (jolgorio); SiLVA MAROTO, red., El Bosco, 298.

${ }^{26}$ Zob. Ludwig von BALDAss, Hieronymus Bosch (New York: Harry N. Abrams, 1960; oryg. Wien 1943), 25; Roger Van Schoute, Dominique Verboomen, Jérôme Bosch (Tournai: Renaissance du Livre, 2001), 140; Silver, Hieronymus Bosch, 270; Charles D. CUTTLER, Hieronymus Bosch. Late Work (London: Pindar Press, 2012), 56; Fischer, Hieronymus Bosch, 201; Silva MARото, red., El Bosco, 287 (P. Silva Maroto). Walter S. Gibson i Laurinda Dixon, omawiając analizowaną scenę, przywołują myśli Aureliusza Prudencjusza Klemensa (IV wiek) i Grzegorza Wielkiego (ok. 540-604), którzy dopatrywali się związku między nieczystością a chciwością; GIBSON, Hieronymus Bosch, 72; DıxON, Hieronymus Bosch, 112-113. Laurinda Dixon proponuje także inną interpretację sceny $\mathrm{z}$ tryptyku madryckiego. Zestawiając śpiewający duet z kochankami w zaroślach oraz grupę muzykujących z pozostałymi osobami, wskazuje na możliwe pary pojęć pozostające w opozycji: miłość duchowa - miłość fizyczna, harmonia - chaos (tamże, 113).

${ }^{27}$ Jeszcze jedna spacerująca para została namalowana na dalszym planie po prawej stronie. 
„door de billen slaan” (uderzać w pośladki), stanowi aluzję do rozwiązłości ${ }^{28}$. W kontekście grzesznej miłości, oprócz jedzenia i picia, pojawiają się instrumenty muzyczne (harfa oraz flet i bęben) leżące nieużywane na trawie, w najbliższym sąsiedztwie błazna.

Bosch, łącząc przejawy nieczystego zachowania z muzyką, a także jedzeniem i piciem (niebędącymi przedmiotem rozważań w niniejszym artykule ${ }^{29}$ ), ukazał w swoistej symbiozie rudymentarne elementy ówczesnego życia społecznego ${ }^{30}$. Pierwszy $\mathrm{z}$ nich, niemieszczący się $\mathrm{w}$ żadnej mierze w systemie niderlandzkiej etyki świeckiej (burgermoraal) ${ }^{31}$, stanowczo potępiał Kościół, odwołując się do nauki moralnej formułowanej na gruncie biblijnym ${ }^{32}$. Drugi element - muzyka, obecna w liturgii Kościoła w późnym średniowieczu głównie jako śpiew jedno- i wielogłosowy a cappella, w wymiarze czysto instrumentalnym (a także taniec) poddawana była od czasów patrystycznych ostrej krytyce ${ }^{33}$. Obecność instrumentów muzycznych w scenach grzechu nieczystości w malarstwie Boscha nieodparcie przywołuje aspekty realnej praktyki

${ }^{28}$ Zob. Hans van GANGELEN i Sebastiaan OstKamP, „Parallels Between Hieronymus Bosch’s Imagery and Decorated Material Culture from the Period Between circa 1450 and 1525", w Jos KoldeweiJ, Bernard Vermet, Barbera van KoolJ, red., Hieronymus Bosch. New Insights Into His Life and Work (Rotterdam: NAi Publishers, Ludion 2001), 162.

${ }^{29}$ Zob. Gerd UnVerfehrt, Wein statt Wasser. Essen und Trinken bei Jheronimus Bosch (Göttingen: Vandenhoeck und Ruprecht, 2003).

${ }^{30}$ Przekazem literackim rzucającym cenne światło na badaną problematykę jest Pochwała głupoty Erazma z Rotterdamu (1467-1536). W rozprawie z 1509 r., tak oto pisał: „Są jednak niektórzy, a szczególnie podtatusiali, bardziej skorzy do kieliszka niż do kobiety, ci największą rozkosz czerpią w kuflu [...]. Na cóż bowiem nadziewać sobie brzuch tylu przysmakami i łakociami, ładować go tylu wymysłami, skoro przy tym nie tylko oczy i uszy, ale sam nawet umysł nie będą żywione przyjemnością i bawione śmiechem i żartami [...]. Wreszcie i inne w czasie uczt i balów niezbędne rzeczy jako wybór króla, czyli gospodarza balu, gra w karty i fanty, picie kolejno kielichami zdrowia, śpiewy z pucharem w ręku, tańce i skoki” (18). ERAZM z RotTERDAMU, Pochwała glupoty i inne pisma, tłum. b.d. (Warszawa: Hachette, 2011), 30-31.

${ }^{31} \mathrm{Na}$ temat etyki świeckiej w późnym średniowieczu w Niderlandach zob. Herman PLEIJ, Het gilde van de Blauwe Schuit. Literatuur, volksfeest en burgermoraal in de late middeleeuwen (Amsterdam: Meulenhoff, 1983, wyd. 2); IDEM, Op belofte van profijt. Stadsliteratuur en burgermoraal in de Nederlandse letterkunde van de middeleeuwen (Amsterdam: Prometheus, 1991). Problematykę systemu wartości etycznych patrycjatu miejskiego w Brabancji w powiązaniu z malarstwem Boscha podjął Paul VANDENBROECK w pracy Jheronimus Bosch. Tussen volksleven en stadscultuur (Berchem: EPO, 1987); nowe wydanie książki z 1987 r.: IDEM, Jheronimus Bosch. De verlossing van de wereld (Ghent, Amsterdam: Ludion, 2002).

${ }^{32}$ Zob. przyp. 17 i 19.

${ }^{33}$ Do jej najbardziej zagorzałych krytyków w okresie patrystycznym należeli m.in. Jan Chryzostom (ok. 350-407) i Hieronim ze Strydonu (ok. 347-420). Zob. np. Jan Chryzostom, In caput XXIX Genesim, Hom. 56, 1 (PG 54, 486); Hieronim, Epistola 107, 8 (PL 22, 875). Przekłady na język angelski zob. James MCKInNON, red., Music in Early Christian Literature (Cambridge, New York: Cambridge University Press, 1987; repr. 1993), 84, 142. 
wykonawczej w ramach muzykowania prywatnego przełomu XV-XVI wieku ${ }^{34}$. Jednakże brak możliwości weryfikacji audytywnych doświadczeń Boscha wyklucza obszar kultury naznaczony działalnością kompozytorów franko-flamandzkich ${ }^{35} \mathrm{z}$ pogłębionych rozważań muzykologicznych.

Różnorodne wymiary miłości w powiązaniu z muzyką i tańcem (a także jedzeniem i piciem) są reprezentowane w późnośredniowiecznych przedstawieniach rysunkowych, malarskich czy graficznych, takich jak Majowa przejażdzka łodzia, Ogród miłości, Dzieci Wenus. Przykładem ostatniego z wymienionych tematów jest rysunek (fol. 15r) w Mittelalterliche Hausbuch (kolekcja prywatna, do 2008 r. zamek Wolfegg, Kunstsammlungen der Fürsten zu Waldburg-Wolfegg, ok. 1482) ${ }^{36}$ (il. 6). Niewątpliwie, wyłączając nieweryfikowalne doświadczenia własne Boscha, w tej właśnie ikonosferze tkwią główne źródła obrazowania umuzycznionych scen grzechu nieczystości w trzech wzmiankowanych wyżej dziełach malarza.

\section{LUXURIA DAMNATA W OLTARZU SADDU OSTATECZNEGO}

Odnośnie do kary za grzechy nieczystej miłości i uciech cielesnych w $O t-$ tarzu Sądu Ostatecznego z Wiednia najczęściej wskazuje się na scenę (il. 7) znajdującą się po lewej stronie, w środkowej strefie tablicy centralnej ${ }^{37}$. Na prostokątnej platformie obok nagiego mężczyzny śpiącego na czerwonym łóż$\mathrm{ku}$, została przedstawiona, podobnie jak on naga, kobieta z wężem-jaszczurką

${ }^{34}$ Zob. Keith POLK, „Instrumental performance in the Renaissance”, w Colin LAwsON, Robin StOwell, red., The Cambridge History of Musical Performance (Cambridge: Cambridge University Press, 2012), 335-352. Zob. też Victor CoELHO, Keith POLK, Instrumentalists and Renaissance Culture, 1420-1600. Players of Function and Fantasy (Cambridge: Cambridge University Press, 2016).

${ }^{35}$ Szerzej na temat kultury muzycznej w dobie renesansu zob. Reinhard STROHM, Bonnie J. BLACKBURn, red., The New Oxford History of Music. Music as Concept and Practice in the Late Middle Ages, t. 3/1 (Oxford, New York: Oxford University Press, 2001); Anna M. Busse Berger, Jesse RodIn, red., The Cambridge History of Fifteenth-Century Music (Cambridge: Cambridge University Press, 2015; Iain Fenlon, Richard Wistreich, red., The Cambridge History of Sixteenth-Century Music (Cambridge: Cambridge University Press, 2018).

${ }^{36}$ Źródło ilustracji: https://iconographic.warburg.sas.ac.uk (dostęp: 9.08.2019).

${ }^{37}$ BALDAss, Hieronymus Bosch, 30; GIBSON, Hieronymus Bosch, 56; BAX, Hieronymus Bosch and Lucas Cranach, 154-159; Renate TRNEK, Das Weltgerichtstriptychon von Hieronymus Bosch in der Gemäldegalerie der Akademie der bildenden Künste in Wien (Rosenheim: Rosenheimer Verlagshaus, 1989), 42; Silver, Hieronymus Bosch, 347; Fischer, Hieronymus Bosch, 167; Büttner, Nauhaus, Pokorny, Silver, Hieronymus Bosch, 9; Guillaume Cassegrain, Hieronymus Bosch. Triptychs (Vanves: Éditions du Chêne, 2017), 45. Dodajmy, że Nils Büttner uważa, podobnie jak Dirk Bax, że tańcząca kobieta może także personifikować próżność (superbia), a śpiący mężczyzna lenistwo (acedia). 
na łonie, którą do tańca prowadzi smok trzymający w prawej łapie świecę. Pośród kilku infernalnych istot kłębiących się wokół obu postaci dwie oddają się muzykowaniu. Akompaniament do tańca realizuje demon grający na lutni trzymanej w sposób nienaturalny na głowie oraz inny o dziobie zakończonym aerofonem. Stefan Fischer jest jednym z nielicznych współczesnych badaczy, który na tej samej tablicy dostrzega jeszcze jedną aluzję do nieczystości (il. 8). Na prawo od pionowej osi kompozycji, nieco wyżej niż wzmiankowana platforma, kobietę w rogatym czepcu (podwójny hennin) na głowie, stojącą w wejściu do tawerny, interpretuje podobnie jak tę pochylającą się nad śpiącym mężczyzną, jako stręczycielkę nierządu. Wewnątrz zrujnowanego budynku znajduje się jeszcze jedna kobieta, nosząca takie samo nakrycie głowy, oraz mężczyzna. Przed tawerną na ławce siedzi dudziarz opierający się na beczce (na niej dzban na wino), ewokujący zdaniem badacza grzech lenistwa ${ }^{38}$.

Na prawym skrzydle Ottarza penalizacja grzechów nieczystości została przedstawiona w dolnej części tablicy (il. 9.a \& 9.b). W czerwonym namiocie rozkoszy ${ }^{39}$ i wokół niego tłoczą się liczne nagie postaci. Pałac Lucyfera, na którego dachu rozbito ów namiot, jawi się jako miejsce o specyficznej sonosferze. Dwa demony znajdujące się w najbliższym sąsiedztwie potępionych zostały wyposażone w instrumenty muzyczne: flet i bęben oraz trąbkę (została ona wetknięta w odbyt infernalnego muzyka). Po lewej stronie wejścia do przybytku księcia ciemności muzykuje grupa, w składzie której, obok śpiewającej nagiej kobiety oraz demona $\mathrm{z}$ księgą z zapisem nutowym, znajduje się trzech demonów-instrumentalistów z lutnią, trąbką i aerofonem stanowiącym organiczną część dziobu. Towarzyszy im harfista znajdujący się w oknie budowli. Po przeciwnej stronie, przed oblicze władcy piekła prowadzony jest nagi mężczyzna $z$ oczami zawiązanymi przepaską. W jego ciele tkwi miecz, a w odbycie dziób ptaka. Przed obiema grupami, niemalże na wprost Lucyfera widnieje dół wypełniony infernalną fauną. W opinii Ludwiga von Baldass naga postać kobieca reprezentuje duszę potępioną za grzechy rozwiązłości ${ }^{40}$. Z kolei Dirk Bax w kontekście kary za nieczyste zachowanie w życiu ziemskim umieszcza obie postaci ${ }^{41}$.

\footnotetext{
${ }^{38}$ FISCHER, Hieronymus Bosch, 164.

${ }^{39} \mathrm{Na}$ ten motyw szczególną uwagę zwraca Larry Silver. Pisze tak oto: ,above and behind the entry to Hell's walls, a pleasure tent appears, now crammed with despairing rather than delighted nudes, in a reversal of the indulgance of luxuria"; IDEM, Hieronymus Bosch, 347.

${ }^{40}$ Baldass, Hieronymus Bosch, 30.

${ }^{41}$ BAX, Hieronymus Bosch and Lucas Cranach, 222-223, 233-234. Autor kobietę łączy także z pychą (superbia), a mężczyznę ze złością (ira) $(231,235)$.
} 


\section{LUXURIA DAMNATA - ANALIZA I INTERPRETACJA}

\section{CZĘŚĆ ŚRODKOWA OETARZA SĄDU OSTATECZNEGO}

$\mathrm{W}$ pierwszej z wymienionych wyżej scen elementem wykazującym explicite erotyczne konotacje jest czerwone łóżko, locus peccati po drugiej (ziemskiej) stronie życia, a w wizji Boscha miejsce kary ${ }^{42}$. Jako ponadczasowy przedmiot-symbol nie wymaga szerszego komentarza. Odnotujmy jedynie, że łóżko tego samego koloru wraz z parą skazańców zostało ukazane w medalionie przedstawiającym kary odpowiadające siedmiu grzechom głównym na tablicy Siedem Grzechów Głównych i Cztery Rzeczy Ostateczne. Niewątpliwie, oprócz dwóch potępionych dusz ludzkich, z nieczystością należy łączyć stręczycielkę, a zdaniem Dirka Baxa, także jaszczurkę pozbawioną tylnych kończyn oraz dwie istoty wykazujące podobieństwo do ropuchy, znajdujące się na i pod łóżkiem ${ }^{43}$.

Taniec, jaki wykonuje niewiasta prowadzona przez smoka do akompaniamentu duetu instrumentalnego, zdaje się stanowić preludium do aktu mającego rozegrać się przy współudziale mężczyzny i zoomorficznych demonów. To w tej właśnie formie rozrywki Sebastian Brant (1457-1521) dostrzegał poważne zagrożenie dla moralności współczesnych mu ludzi. W Okręcie błaznów, poemacie wydanym w 1494 r., pisał: „Taniec wiele grzechów rodzi,/ Pychę, pijaństwo, obżarstwo,/ Nieczystości sprzyja łatwo:/ Gdy się Wenus mocniej chwyta,/ Cnota dhugo nie wytrzyma" $(61,12-16)^{44}$. Zobrazowana w Oltarzu wiedeńskim tańcząca para przywodzi na myśl podobny motyw z prawego skrzydła tryptyku Ogród Rozkoszy ziemskich (Madryt, Museo Nacional del Prado, ok. 1495-1505) ${ }^{45}$ (il. 10) Boscha, dzieła najprawdopodobniej wcześniejszego niż analizowany tu tryptyk. Na okrągłej platformie umieszczonej na głowie „człowieka-drzewa” określanego przez Reinderta Falkenburga mianem

\footnotetext{
${ }^{42}$ Odnośnie do motywu łóżka w późnośredniowiecznej literaturze niderlandzkiej zob. BAX, Hieronymus Bosch and Lucas Cranach, 158. Motyw ten pojawia się m.in. w Dat sterf boeck ([Ars moriendi], fol. 65r, 120r), inkunabule wydanym w 1488 r. w Zwolle i Delft. Na gruncie malarstwa miniatorskiego jako przykład sceny erotycznej rozgrywającej się w łóżku można wskazać iluminację (fol. 6r) w Talbot Shrewsbury Book (Londyn, The British Library, MS Royal 15 E VI, 1444-1445).

${ }^{43}$ Zob. BAX, Hieronymus Bosch and Lucas Cranach, 156. Podobne konotacje zdaniem badacza wykazują też inne demony ukazane w tej scenie (157).

${ }^{44}$ Sebastian BRANT, Okręt błaznów, tłum. Andrzej Lam (Pułtusk: Akademia Humanistyczna im. A. Gieysztora 2010), 151.

${ }^{45}$ Ilsink, Koldeweid, Spronk [i in.], Hieronymus Bosch, 356-379. Wcześniejszą datację (ok. 1490-1500), proponuje Pilar Silva Maroto, El Bosco, 330-346.
} 
„Zwierciadła rozwiązłości”46, wokół centralnie usytuowanych dud, tańczą trzy (być może za dudami kryje się jeszcze jedna) pary. Identyfikacji demonów prowadzących potępionych podjął się Dirk Bax; w jego opinii są to: pośredniczka w nierządzie (copulatrix), właściciel domu publicznego i prostytutka (meretrix) ${ }^{47}$. Tańczące nagie postaci, jak wyżej w kręgu, w którego centrum znajdują się dudy (tym razem nie różowe, lecz niebieskie), widnieją również na tablicy środkowej Ottarza Sądu Ostatecznego z Brugii (Groeningemuseum, ok. 1495-1505) ${ }^{48}$, uważanego dzisiaj za własnoręczne dzieło Boscha.

Oprócz dzieł literackich za najważniejsze źródła inspiracji Boscha uważane są peryferyjne obszary sztuki: drôleries z malarstwa miniaturowego oraz rzeźba architektoniczna i ornamentalna budowli sakralnych ${ }^{49}$. Liczne przedstawienia tańca, w tym z wyraźnymi aluzjami do rozwiązłości, zawierają iluminowane kodeksy. Pośród kilku miniatur w Breviari d'Amor Matfrego Ermengaud (Londyn, The British Library, MS Royal 19 C I, ok. 1300-1325) s0 $^{50}$ (i1. 11), przedstawiających kuszenia kochanków, jedna (fol. 204v) ukazuje taniec pięciu osób z kręgów dworskich. Przewodzi im diabeł, któremu towarzyszą dwaj przedstawiciele świata zła grający na trąbkach. Z kolei jedna $\mathrm{z}$ miniatur (fol. 21v) w Roman d'Alexandre (Oxford, The Bodleian Libraries, MS Bodl. 264, ok. 1338-1344) $)^{51}$, przedstawia mnicha unoszącego w górę prawą rękę i w lewej trzymającego pałkę, zdającego się powstrzymywać, a może wręcz potępiać taneczny korowód pięciu postaci poruszających się do akompaniamentu chordofonu. Prowadzi go osoba przebrana za jelenia, w dalszej kolejności znajdują się: kobieta, dwóch mężczyzn przebranych za zająca i wilka oraz jeszcze jedna kobieta. W dolnej części miniatury (fol. 36v) w Cité de Dieu św. Augustyna (Haga, Koninklijke Bibliotheek, MS RMMW, 10 A 11, ok. 1475) ${ }^{52}$ (il. 12), zostało ukazanych w tańcu pięć nagich osób: dwie kobiety oraz trzech mężczyzn w maskach, a w roli akompaniatora również nagi muzyk grający na flecie i bębnie. W kręgu oddziaływań źródłowych sytuują się także umuzycznione przedstawienia tańca śmierci (danse macabre). Znakomitą

\footnotetext{
${ }^{46}$ Reindert Falkenburg, The Land of Unlikeness. Hieronymus Bosch, The Garden of Earthly Delights (Zwolle: W Books, 2011), 234 (speculum of Luxuria).

${ }^{47}$ Dirk BaX, Hieronymus Bosch, his picture-writing deciphered (Rotterdam: Balkema, 1979), 240. Zdaniem badacza dudy obsługuje conciliatrix.

${ }^{48}$ Ilsink, KoldeweiJ, Spronk [i in.], Hieronymus Bosch, 278-289.

${ }^{49}$ Zob. Eric De Bruyn, „Textos e imágenes. Las fuentes del arte del Bosco”, w Silva Maroto, red., El Bosco, 73-89.

${ }^{50}$ Źródło ilustracji: http://www.bl.uk (dostęp: 17.08.2019).

${ }^{51}$ Źródło ilustracji: http://image.ox.ac.uk (dostęp: 17.08.2019).

52 Źródło ilustracji: http://manuscripts.kb.nl (dostęp: 17.08.2019).
} 
egzepmifikacją są ilustracje w inkunabule Der doten dantz mit figuren/clage vnd antwort schon/von allen staten der werlt (Heidelberg, Universitätsbibliothek, GW-M47257, ok. 1488) ) $^{53}$. Jedna z nich (fol. 20r) ukazuje młodą kobietę prowadzoną przez śmierć $\mathrm{z}$ wężem w szczęce i ropuchą na czaszce.

Instrumenty przedstawione w emblematycznej scenie z Ottarza wiedeńskiego należały w czasach malarza do powszechnie używanych ${ }^{54}$. Lutnia, podobnie jak harfa, reprezentuje chordofon melodyczny z grupy instrumentów cichych (basse musique), wykorzystywany w muzykowaniu kameralnym. Z kolei aerofon demona-muzyka, będący organiczną częścią jego dziobu, przypomina szałamaję, instrument dęty głośny (haute musique), wchodzący zazwyczaj w skład zespołu typu alta cappella (szałamaje i trąbki suwakowe) ${ }^{55}$. Zauważmy, że w XV-wiecznej praktyce wykonawczej nie łączono obu razem, a lutnia nie stanowiła typowego instrumentu do realizacji akompaniamentu do tańca. Geneza osobliwego duetu w składzie lutnia - „organiczna” szałamaja tkwi w malarstwie książkowym ${ }^{56}$. Oryginalne motywy muzyczne zdobią m.in. marginesy Psatterza Rutlandów (Londyn, The British Library,

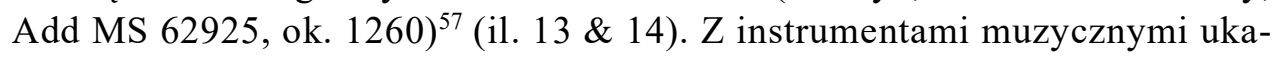
zano na nich oprócz ludzi rozmaite hybrydyczne istoty fantastyczne i zwierzęta (np. fol. $45 \mathrm{r}, 49 \mathrm{v}, 52 \mathrm{v}, 53 \mathrm{v}, 54 \mathrm{v}, 54 \mathrm{r}, 56 \mathrm{v})$. Jako pierwowzór muzyka

${ }^{53}$ Źródło ilustracji: http://digi.ub.uni-heidelberg.de (dostęp: 17.08.2019).

${ }^{54}$ Wykaz instrumentów muzycznych zobrazowanych przez Boscha i jego pracownię zob. Kees VelleKoop, „Music and Dance in the Paintings of Hieronymus Bosch”, w Koldeweis, Vermet, KooIJ, Hieronymus Bosch, 201-205. Szerzej na temat instrumentów muzycznych, w tym problematyki organologicznej, zob. Jeremy MonTAGU, The World of Medieval and Renaissance Musical Instruments (Woodstock NY: Overlook Press, 1976; repr. 1980); David MunRow, Instruments of the Middle Ages and Renaissance (London: Oxford University Press, 1976).

${ }^{55}$ Odnotujmy, że władze miejskie 's-Hertogenbosch w latach 1500-1530 zatrudniały czterech muzyków (stad pijpers, scalmeyers) grających na szałamajach i trąbkach. Zob. Keith PoLK, „Ensemble Instrumental Music in Flanders - 1450-1550", Journal of Band Research 11(1975): 13 (tabela 1).

${ }^{56}$ Odnośnie do związków pomiędzy malarstwem miniatorskim a tablicowym Boscha zob. Suzanne SulzBERGER, „Jérôme Bosch et les maîtres de l'enluminure”, Scriptorium 16(1962): 46-49; Erwin POKORNY, „Bosch and the Influence of Flemish Book Illumination”, w Jill BRADLEY, Eric De Bruyn, Jos Koldeweid, Thomas VRIEns, red., Jheronimus Bosch. His Sources. 2nd International Jheronimus Bosch Conference, May 22-25, 2007, 's-Hertogenbosch, The Netherlands, Jheronimus Bosch Art Center ('s-Hertogenbosch: Jheronimus Bosch Art Center, 2010), 281-292. Zob. też Thomas KREN, Maryann W. AINSWORTH, „Illuminators and Painters. Artistic Exchanges and Interrelationships", w Thomas KREN, Scot MCKENDRICK, red., Illuminating the Renaissance. The Triumph of Flemish Manuscript Painting in Europe (Los Angeles: Getty Publications, 2003), 35-57 (w szczególności s. 44-47).

${ }^{57}$ Źródło ilustracji: http://www.bl.uk (dostęp: 20.08.2019). W ikonografii średniowiecznej $\mathrm{z}$ instrumentami muzycznymi oprócz istot fantastycznych i zwierząt powszechnie ukazywano aniołów oraz muzyków świeckich, a pośród nich m.in. króla Dawida. 
o dziobie zakończonym aerofonem wskazuje się zoomorficznego stwora przedstawionego na prawym marginesie miniatury (fol. 7r) w Mszale Richarda Chambellana (Paryż, Bibliothèque nationale de France, MS lat. 879, ok. 14751500). ${ }^{58}$ Demon-muzyk o podobnej budowie dziobu widnieje też na środkowej tablicy tryptyku Kuszenia św. Antoniego (Lizbona, Museu Nacional de Arte Antiga, ok. 1500-1510) ${ }^{59}$. Dodajmy, że lutnistę wywodzącego się z tego samego świata, grającego na instrumencie w sposób nienaturalny znajdujemy w wytworze warsztatu malarza: Po Sadzie Ostatecznym (Rotterdam, Museum Boijmans Van Beuningen, ok. 1510-1520) ${ }^{60}$ oraz w tryptyku z Lizbony.

Scena, na którą zwrócił uwagę Stefan Fischer, przywołuje realia historyczne, gdyż wiemy, że muzycy występowali w domach publicznych i innych miejscach o wątpliwej reputacji. Miniatura (fol. 244r) w Facta et dicta memorabilia Waleriusza Maksymusa (Berlin, Staatsbibliothek, MS Dep. Breslau 2, vol. 2, ok. 1470) ${ }^{61}$ (il. 15) ukazująca łaźnię, jest potwierdzeniem zachowanych przekazów literackich ${ }^{62}$. Muzyk towarzyszący nagim postaciom, w miejscu będącym w istocie tolerowanym w niektórych średniowiecznych miastach domem schadzek, gra na lutni. Obecność w obrazie wiedeńskim instrumentalisty właśnie $\mathrm{z}$ dudami przed wejściem do tawerny zapewne nie jest przypadkowa. Ów instrument wykorzystywany w akompaniamencie do tańca, ze względu na anatomiczne podobieństwo do męskich genitaliów, zwłaszcza gdy ukazywany w kolorze różowym lub czerwonym, obdarzony był w późnym średniowieczu wybitnie erotyczną symboliką ${ }^{63}$. Bosch $w$ swoich dziełach

${ }^{58} \mathrm{BAX}$, Hieronymus Bosch, his picture-writing deciphered, 349-350. Odnotujmy, że na fol. 7r w Mszale Richarda Chambellana pierwszy zwrócił uwagę Jacques Combe omawiając scenę na szczycie madryckiego Wozu z sianem; IDEM, Hieronymus Bosch (London: B.T. Batsford, 1946; oryg. Paris 1946), 8, przyp. 53. Reprodukcję miniatury zawiera dodatek z ilustracjami (Planches) $\mathrm{w}$ : Victor LeROQUAIS, Les sacramentaires et les missels manuscrits des bibliothèques publiques de France, t. 1-3 (Paris: Abbé V. Leroquais, 1924), il. 105. Mszat w formacie cyfrowym nie jest dostępny ani na stronie: https://gallica.bnf.fr, ani na innej dedykowanej iluminowanym kodeksom przechowywanym w Bibliothèque nationale de France: http://mandragore.bnf.fr.

${ }^{59}$ Ilsink, KoldeweiJ, Spronk [i in.], Hieronymus Bosch, 140-159.

${ }^{60}$ Tamże, 380-391.

${ }^{61}$ Reprodukcję fol. 244r zawiera praca: Maurits SMEYERS, Flemish Miniatures from the 8th to the mid-16th Century. The Medieval World on Parchment (Leuven: Davidsfonds, 1999), 369, il. 22.

${ }^{62}$ Zob. BAX, Hieronymus Bosch and Lucas Cranach, 140, 156-157, 233, 240. Na temat prostytucji w średniowiecznej Europie zob. Vern L. Bullough, „Prostitution in the Later Middle Ages”, w Bullough, Brundage, red., Sexual Practices and the Medieval Church, 176-186, 275-277; Jacques Rossiaud, La prostitution médiévale (Paris: Flammarion, 1988); Ruth MAzo KARRAS, „Prostitution in Medieval Europe”, w Bullough, Brundage, red., Handbook of Medieval Sexuality, 243-260.

${ }^{63}$ Zob. John H. Planer, „Damned Music. The Symbolism of the Bagpipes in Art of Hieronymus Bosch and his Followers", w Carmelo P. Comberiati, Matthew C. STEEL, red., Music from 
oprócz samoistnie grających dud, w roli dudziarza ukazał ludzi i demona. Ten ostatni pojawia się na lewym skrzydle tryptyku Kuszenia św. Antoniego.

\section{PRAWE SKRZYDŁO OETARZA SADUU OSTATECZNEGO}

Czerwony namiot, będący jednym z najbardziej wyeksponowanych wizualnie elementów na prawym skrzydle Ottarza z Wiednia, stanowi miejsce retrybucji za nieczyste uczynki duszy i ciała. Skazani na wieczne potępienie doświadczają kar zmysłów par excellence. Oprócz dotyku, torturom poddawane są też zmysły wzroku, słuchu i węchu (w namiocie płonie ogień, a przez wejście unosi się dym). Motywem namiotu rozkoszy Bosch posłużył się uprzednio w Ottarzu Sadu Ostatecznego z Brugii oraz na lewym skrzydle Tryptyku Wędrowca. Odnajdujemy go też na tablicy Siedem Grzechów Głównych i Cztery Rzeczy Ostateczne. Motyw namiotu występujący powszechnie w ikonografii związanej z tematyką militarną uobecnia się także $\mathrm{w}$ przedstawieniach Dzieci Wenus. Spotykamy go m.in. w miniaturach (odpowiednio fol. 12v i fol. 31v) w Diversarius multarum materiarum Gallusa Kemli (Zurych, Zentralbibliothek, MS C 101, XV wiek) ${ }^{64}$ oraz w Boke of Astronomy and off Philosophye' (Oxford, The Bodleian Libraries, MS Rawl. D. 1220, ok. 1450-1475) ${ }^{65}$.

Demon z bębnem i fletem, instrumentami wykorzystywanymi w XV wieku - podobnie jak dudy - do realizacji akompaniamentu do tańca, przywołuje ziemski kontekst grzechu - nieokiełznanej aktywności ruchowej będącej jednym z przejawów nieczystego zachowania. Oba instrumenty przynależą w najwyższym stopniu do sfery profanum. W miniaturze (fol. 160v) w Pèlerinage de vie humaine (Paryż, Bibliothèque nationale de France, MS Français 829,

the Middle Ages through the Twentieth Century. Essays in Honor of Gwynn S. McPee (New York: Gordon and Breach Science Publishers, 1988), 335-353. Autor wywodzi erotyczną symbolikę dud ze środowiska tańców wiejskich. W średniowieczu powszechne były dwie formy tańca grupowego: taniec kołowy i taniec liniowy. Szczególną popularnością na dworze burgundzkim cieszył się basse danse wykonywany w parach. Szerzej na temat tańca w XV i XVI wieku zob. Ingrid BRAINARD, The Art of Courtly Dancing in the Early Renaissance, t. 1-2 (West Newton MA: Brainard, 1981); Peggy Dixon, Dances from the Courts of Europe, t. 1 (London: Nonsuch History and Dance, 1999); Margaret M. McGowan, Dance in the Renaissance. European Fashion, French Obsession (New Haven, London: Yale University Press, 2008); Robert Mullally, The Carole. A Study of a Medieval Dance (Farnham, Burlington VT: Ashgate, 2011). Zob. też Timothy J. McGeE, Medieval Instrumental Dances (Bloomington IN: Indiana University Press, 1990).

${ }^{64}$ Źródło ilustracji: http://www.e-codices.unifr.ch (dostęp: 23.08.2019).

${ }^{65}$ Źródło ilustracji: http://bodley30.bodley.ox.ac.uk (dostęp: 23.08.2019). 
ok. $1400-1410)^{66}$ z podwójnym fletem i bębnem przedstawiono diabły. Trąbki w średniowiecznej Europie, pełniące m.in. funkcje aerofonów reprezentacyjnych $^{67}$, wyposażano $\mathrm{w}$ chorągwie $\mathrm{z}$ herbem potwierdzającym tożsamość zwierzchnika lennego ${ }^{68}$. W Ottarzu wiedeńskim, jak unaocznił malarz, status instrumentu uległ „profanacji”. Obsceniczny sposób gry na tym dystyngowanym aerofonie ma swój wcześniejszy odpowiednik na prawym skrzydle tryptyku Ogród rozkoszy ziemskich. Między pośladkami grzesznika widnieje flet. Taki sposób wydobywania dźwięków, ewokujący różnorakie aspekty nieczystości skatologicznej ${ }^{69}$, może odnosić się do natury przewinień potępionych. Motyw trąbki przykładanej do nieodpowiedniej części ciała ludzkiego jest znany w ikonografii średniowiecznej na długo przed jego pojawieniem się w dziełach Boscha. Miniatura (fol. 134r) w Kantykach Rothschilda (New Haven, Beinecke Rare Book \& Manuscript Library, MS 404, ok. 1300) $)^{70}$ ukazuje mężczyznę z jednym instrumentem, natomiast miniatura (fol. 157r) w Godzinkach wykonanych na użytek diecezji Cambrai (Baltimore, The Walters Art Museum, MS W.88, ok. 1300-1310) ${ }^{71}$ (il. 16) przedstawia muzyka obsługującego jednocześnie dwa instrumenty.

\footnotetext{
${ }^{66}$ Źródło ilustracji: http://gallica.bnf.fr (dostęp: 23.08.2019).

${ }^{67}$ W państwie burgundzkim za panowania Karola Śmiałego (1432-1477), w 1469 r. zespół muzyków grających na trompettes de guerre (trąbki naturalne) liczył pięciu członków, w 1474 r. został powiększony do dwunastu. Ensemble tej wielkości funkcjonował także na dworze Filipa I Pięknego. Zob. David FALlOWS, „Specific information on the ensembles for composed polyphony, 14001474", w Stanley Boorman, red., Studies in the performance of late mediaeval music (Cambridge: Cambridge University Press, 1983; repr. 2008), 146; Martin PICKER, „The Habsburg Courts in the Netherlands and Austria, 1477-1530”, w Iain FENLON, red., The Renaissance. From the 1470s to the end of the 16th century (Basingstoke-London: Macmillan Press, 1989), 219, 221. Podstawowe informacje na temat trompettes de guerre i trompettes des ménestrels zob. Edward TARR, The Trumpet (London: Batsford, 1988), 55-56.

${ }^{68}$ Zob. Curt SaChS, The History of Musical Instruments (London: J.M. Dent and Sons Ltd., 1942; repr. 1978), 281; TARR, The Trumpet, 43-44.

${ }^{69}$ Zob. K.P. WENTERSDORF, „The symbolic significance of figurae scatologicae in Gothic manuscripts", w Clifford DAVIDSON, red., Word, Picture, and Spectacle (Kalamazoo MI: Medieval Institute Publications, 1984), 1-19; Valerie ALLEN, On Farting. Language and Laughter in the Middle Ages (New York: Palgrave Macmillan, 2007); Anja GreBE, „Inside Out. Scatology in Medieval Art", w Kassandra NAKAS, Jessica Ullrich, red., Scenes of the Obscene. The Non-Representable in Art and Visual Culture, Middle Ages to Today (Weimar: VDG, 2014), 13-36. Warto w tym miejscu przywołać osobliwą - jeżeli weźmiemy pod uwagę charakter cytowanego dzieła wypowiedź św. Augustyna: „Wiemy, że i ludzie niektórzy mają naturę odmienną od innych ludzi, naturę dziwną [...]. Inną dolną część tułowia [sic!], bez żadnego plugastwa, tak rozmaite wedle woli dźwięki wydają, że wydaje się, jak gdyby tamtą częścią śpiewali”, św. Augustyn, Państwo Boże, 14,24, thum. Władysław Kubicki (Kęty: Antyk, 2002, wyd. 2), 542.

${ }^{70}$ Źródło ilustracji: https://brbl-dl.library.yale.edu (dostęp: 23.08.2019).

${ }^{71}$ Źródło ilustracji: http://www.thedigitalwalters.org (dostęp: 23.08.2019).
} 
Św. Augustyn (354-430) w Wyznaniach pisał: „Coraz bardziej jednak skłaniam się do pochwalania tego obyczaju, że śpiewa się w kościele, aby poprzez przyjemność uszu mogła słabsza dusza wznosić się do stanu pobożności. Poczytuję to jednak sobie za karygodny grzech, ilekroć tak się zdarza, że bardziej mnie porusza sam śpiew niż to, o czym się śpiewa. W takich wypadkach lepiej by było, gdybym nie słyszał śpiewu" $(10,33) .{ }^{72}$ Jeżeli śpiew religijny ${ }^{73}$ może być czynnością grzeszną, czym zatem są utwory świeckie opiewające miłość cielesną ${ }^{74}$ wykonywane przy akompaniamencie instrumentów muzycznych? Karą dla niewiasty jest wymuszona aktywność wokalna w obecności demonówmuzyków. „Wita” ona śpiewem - najprawdopodobniej za życia nazbyt gorliwie oddawała się tej aktywności - wszystkich udających się przez bramę pałacu księcia piekła do namiotu rozkoszy. Motywem infernalnego śpiewu Bosch posłużył się już wcześniej, m.in. na prawym skrzydle tryptyku Ogród rozkoszy ziemskich, a zapis nutowy widnieje w księdze oraz na pośladkach jednego z potępionych. Dirk Bax uważał, że ptak (mogący w pewnych kontekstach pełnić funkcję symbolu fallicznego) z dziobem w tylnej części ciała mężczyzny stanowi wyraźną aluzję do nieczystości. Samego zaś skazańca określił jako kaasjager (dosł. ścigający ser; wyraz kaas odnosił się niegdyś do pośladków), czyli osoby uganiającej się za kobietami ${ }^{75}$. Sposób, w jaki demon gra na harfie, trzymanej nienaturalnie nad głową (podobnie jak demon-lutnista), pozwala wnioskować na temat charakteru muzyki, będącej niewątpliwie kreacją dźwiękową „na wspak". Jej istotą jest udręka zmysłu słuchu, jakże ważnego w ars amandi. Na amuzyczny charakter gry, a tym samym specyficzny rodzaj kar wymierzanych przez demony, wskazują dwa pozostałe aerofony infernalnych muzyków. Z instrumentu skierowanego $\mathrm{w}$ stronę potępionej kobiety wylatują fekalia symbolizujące nieczystość ${ }^{76}$, a z czary głosowej instrumentu-dziobu wychodzi ogień.

72 Św. Augustyn, Wyznania, tłum. Zygmunt Kubiak (Kraków: Znak, 1994, wyd. 5), 242.

${ }^{73}$ Muzykę wokalną w 's-Hertogenbosch pielęgnowało m.in. założone w 1318 r. bractwo maryjne Illustre Lieve Vrouwe Broederschap, związane z kościołem św. Jana (Sint-Janskerk; od 1559 r. katedra). Jego członkiem był Bosch. Zob. Albert SMIJERS, De Illustre lieve Vrouwe Broederschap te 's-Hertogenbosch (Amsterdam: b.d., 1932).

${ }^{74}$ Literatuta poświęcona pieśni erotycznej w średniowieczu jest niezwykle obszerna; zob. m.in. Gaby HeRCHERT, 'Acker mir mein bestes Feld'. Untersuchungen zu erotischen Liederbuchliedern des späten Mittelalters. Mit Wörterbuch und Textsammlung (Münster, New York: Waxmann, 1996); Gale Sigal, Erotic Dawn-Songs of the Middle Ages. Voicing the Lyric Lady (Gainesville FL: University Press of Florida, 1996); Julia Wingo SHINNICK, „Singing Desire. Musical Innuendo in Troubadour and Trouvère Song", w Albrecht ClASSEN, red., Sexuality in the Middle Ages and Early Modern Times. New Approaches to a Fundamental Cultural-Historical and Literary-Anthropological Theme (Berlin: Walter de Gruyter, 2008), 293-324.

${ }^{75} \mathrm{BAX}$, Hieronymus Bosch and Lucas Cranach, 222-223.

${ }^{76}$ Zob. przyp. 69. 
W malarstwie tablicowym po motyw trąbki ogniowej sięgnął Stefan Lochner (ok. 1400/10-1451) w Sadzie Ostatecznym (Kolonia, Wallraf-RichartzMuseum \& Fondation Corboud, ok. 1435) (il. 17). Na trąbce gra rogata postać w piekle; obok niej demon z bębnem. Warto w tym miejscu zwrócić uwagę, że motywy muzyczne w przedstawieniach piekła pojawiają się stosunkowo rzadko. Instrumentarium diabłów/ demonów obejmuje zazwyczaj trąbki, rogi, dudy oraz bębny. Jako przykłady można wskazać iluminacje w De civitate Dei św. Augustyna (Bruksela, Koninklijke Bibliotheek van België, MS 9006, ok. 1420-1435) ${ }^{77}$ oraz Schachzabelbuch Konrada von Ammenhausen (Stuttgart, Württembergische Landesbibliothek, MS Cod.poet.et phil.fol.2, 1467) ${ }^{78}$. Miniatura (fol. 265v) w tekście św. Augustyna ukazuje piekło, w którym pośród diabłów tortutujących potępieńców jeden gra na dudach, zaś miniatura (fol. 97v) w Schachzabelbuch przedstawia diabła dmącego w róg, siedzącego na paszczy Lewiatana ziejącej ogniem.

\section{INWERSJA MOTYWÓW ANIOŁA-FANFARZYSTY, BRAMY RAJSKIEJ I MUSICA COELESTIS}

Liczne średniowieczne przedstawienia Sąu Ostatecznego oprócz właściwej sceny Sądu z kanonicznymi figurami, zawierają wyobrażenia nieba i piekła. W tych pierwszych czasami pojawiają się aniołowie-muzycy. Hans Memling (ok. 1435-1494) np. na lewym skrzydle Ottarza Sadu Ostatecznego (Gdańsk, Muzeum Narodowe, 1467-1471) (i1. 18) ukazał bramę rajską, do której prowadzą schody. Zbawionych wita św. Piotr i aniołowie. Skrzydlaci muzycy zostali rozmieszczeni na dwóch poziomach bramy. Z niższego ganku po lewej stronie śpiewa tercet posługujący się księgą, po przeciwnej stronie rozbrzmiewa muzyka realizowana przez trio w składzie: harfa, lutnia i fidel. Na balkonie wieńczącym gotycką budowlę znajduje się ośmiu aniołów, pośród których sześciu gra na instrumentach muzycznych: szałamai, podwójnie zwiniętej trąbce, dwóch ręcznych dzwonkach, lirze korbowej, portatywie i zapewne kolejnej szałamai (widoczny jest tylko fragment instrumentu). Bosch w ramach gry z ikonografią eschatologicznego tematu, ukazując na prawym skrzydle Ołtarza z Wiednia jeden z wymiarów rzeczywistości ostatecznej, posłużył się toposem anioła-fanfarzysty oraz motywami bramy rajskiej i musica coelestis,

\footnotetext{
77 Źródło ilustracji: https://www.kbr.be/nl (dostęp: 24.08.2019).

${ }^{78}$ Źródło ilustracji: http://digital.wlb-stuttgart.de (dostęp: 24.08.2019).
} 
jednakże w odbiciu lustrzanym poddanym artystycznej „dystorsji”79. W funkcji trębacza wskazującego potępionej ludzkości, owej - posługując się terminem św. Augustyna - massa damnata, centrum piekła, wzywając jednocześnie przed oblicze Lucyfera wszystkich potępionych, występuje postać na szczycie namiotu rozkoszy. $Z$ trąbki wykorzystywanej $\mathrm{w}$ nienaturalny sposób zwisa chorągiew, podobnie jak w instrumentach, którymi posługują się aniołowietrębacze heraldyczni ${ }^{80}$ w Ottarzu Sąu Ostatecznego z Brugii. Skazanych na wieczne męki wita przed pałacem sam Lucyfer. Oprócz uzbrojonej gwardii przybocznej (demony prowadzące mężczyznę) towarzyszą mu muzycy, których występ stanowi odwrotność eufonicznego brzmienia zespołu anielskiego przedstawionego na lewym skrzydle tryptyku z Gdańska.

\section{BIBLIOGRAFIA}

Allen, Valerie. On Farting. Language and Laughter in the Middle Ages. New York: Palgrave Macmillan, 2007.

BALDASS, Ludwig von. Hieronymus Bosch. New York: Harry N. Abrams, 1960; oryg. Wien, 1943.

BAX, Dirk. Hieronymus Bosch and Lucas Cranach. Two Last Judgement Triptychs. Description and exposition. Amsterdam: North-Holland Publishing Company, 1983.

BAX, Dirk. Hieronymus Bosch, his picture-writing deciphered. Rotterdam: Balkema, 1979.

Boorman, Stanley, red. Studies in the performance of late mediaeval music. Cambridge: Cambridge University Press, 1983; repr. 2008.

Bradley, Jill i Eric De Bruyn, Jos Koldeweis, Thomas Vriens, red. Jheronimus Bosch. His Sources. 2nd International Jheronimus Bosch Conference, May 22-25, 2007, 's-Hertogenbosch, The Netherlands, Jheronimus Bosch Art Center. 's-Hertogenbosch: Jheronimus Bosch Art Center, 2010.

Brant, Sebastian. Okręt błaznów. Tłumaczył Andrzej Lam. Pułtusk: Akademia Humanistyczna im. A. Gieysztora, 2010.

BRENK, Beat. „Weltgericht”. W Engelbert KIRSCHBAUM, red. Lexikon der Christlichen Ikonographie, t. 4. Rom-Freiburg-Basel-Wien: Gerd Mohn, 1972.

\footnotetext{
${ }^{79}$ Reinhold Hammerstein scenę muzyczną na prawym skrzydle Ottarza interpretował jako parodię liturgii niebiańskiej; IDEM, Diabolus in musica, 100. Na temat świata „,na wspak” w malarstwie Boscha zob. Gloria VAlLESE, „Follia e Mondo alla Rovescia nel 'Giardino delle Delizie' di Bosch”, Paragone 447(1987): 3-22; Keith MoXEY, „Hieronymus Bosch and the 'World Upside Down'. The Case of The Garden of Earthly Delights", w Norman Bryson, Michael Ann Holly, Keith MoXeY, red., Visual Culture. Images and Interpretations (Middletown CT: Wesleyan University Press, 1994), 104-140; GAngelen, OstKamP, „Parallels Between Hieronymus Bosch's Imagery and Decorated Material Culture", 153-169.

${ }^{80}$ Wówczas gdy zadania aniołów dmących w trąbki lub rogi odpowiadają nowotestamentalnym przekazom paruzyjnym (Mt 24,31; 1Kor 15,52; 1Tes 4,16), można ich określać mianem fanfarzystów sensu stricto eschatologicznych.
} 
Brundage, James A. Law, Sex, and Christian Society in Medieval Europe. Chicago-London: University of Chicago Press, 1987; repr. 1990.

Bryson, Norman, Michael Ann Holly, Keith Moxey, red. Visual Culture. Images and Interpretations. Middletown CT: Wesleyan University Press, 1994.

Bullough, Vern L. i James Brundage, red. Handbook of Medieval Sexuality. New York, Abingdon OX: Routledge, 1996; repr. 2010.

Bullough, Vern L. i James A. Brundage, red. Sexual Practices and the Medieval Church. Buffalo NY: Prometheus Books, 1982.

Busse Berger Anna M. i Jesse Rodin, red. The Cambridge History of Fifteenth-Century Music. Cambridge: Cambridge University Press, 2015.

BütTner, Nils i Julia M. NAuHaus, Erwin PoKorny, Larry Silver. Hieronymus Bosch in the Academy of Fine Arts Vienna. Vienna: Bibliothek der Provinz, 2017.

CASAgrande, Carla i Silvana Vecchio. I sette vizi capitali. Storia dei peccati nel Medioevo. Torino: Einaudi, 2000.

Christe, Yves. „Giudizio Universale”. W Angiola M. RomaninI, red. Enciclopedia dell'Arte Medievale, t. 6. Roma: Istituto della Enciclopedia Italiana, 1995.

Christe, Yves. Jugements derniers. Chantilly: ZODIAQUE, 2000.

Classen, Albrecht i Connie Scarborough, red. Crime and Punishment in the Middle Ages and Early Modern Age. Mental-Historical Investigations of Basic Human Problems and Social Responses. Berlin-Boston: Walter de Gruyter, 2012.

Classen, Albrecht, red. Sexuality in the Middle Ages and Early Modern Times. New Approaches to a Fundamental Cultural-Historical and Literary-Anthropological Theme. Berlin: Walter de Gruyter, 2008.

Coelho, Victor i Keith Polk. Instrumentalists and Renaissance Culture, 1420-1600. Players of Function and Fantasy. Cambridge: Cambridge University Press, 2016.

CutTler, Charles D. Hieronymus Bosch. Late Work. London: Pindar Press, 2012.

DıJCK, Godfried C.M. van. Op zoek naar Jheronimus van Aken alias Bosch. De feiten, familie, vrienden en opdrachtgevers, ca. 1400 - ca. 1635. Zaltbommel: Europese Bibliotheek, 2001.

Dixon, Laurinda. Hieronymus Bosch. New York: Phaidon, 2003; repr. 2006.

FEnLON, Iain i Richard WistreICH, red. The Cambridge History of Sixteenth-Century Music. Cambridge: Cambridge University Press, 2018.

FEnLON, Iain, red. The Renaissance. From the 1470s to the end of the 16th century. BasingstokeLondon: Macmillan Press, 1989.

FISCHER, Stefan. Hieronymus Bosch. The Complete Works. Köln: Taschen, 2013.

GiBson, Walter S. Hieronymus Bosch. London: Thames and Hudson, 1973; repr. 2001.

HAMmERSTEIN, Reinhold. Diabolus in musica. Studien zur Ikonographie der Musik im Mittelalter. Bern: Francke, 1974.

Harang, Faustine. La Torture au Moyen Âge, XIVe-XVe siècles. Paris: Presses Universitaires de France, 2017.

HERCHERT, Gaby. 'Acker mir mein bestes Feld'. Untersuchungen zu erotischen Liederbuchliedern des späten Mittelalters. Mit Wörterbuch und Textsammlung. Münster-New York: Waxmann, 1996. 
Ilsink, Matthijs i Jos KoldeweiJ, Ron Spronk, Luuk Hoogstede, Robert G. Erdmann, Rik Klein Gotink, Hanneke NAP, Daan Veldhuizen. Hieronymus Bosch, Painter and Draughtsman. Catalogue Raisonné. Brussels: Mercatorfonds, 2016.

Kemp, Frances i Jos Koldewei, Hannah GooIKer, red. Jheronimus Bosch. His Patrons and his Public. 3rd International Jheronimus Bosch Conference, September 16-18, 2012 Jheronimus Bosch Art Center, 's-Hertogenbosch The Netherlands. 's-Hertogenbosch: Jheronimus Bosch Art Center, 2014.

Koldeweis, Jos, Bernard Vermet, Barbera van KooIJ, red. Hieronymus Bosch. New Insights Into His Life and Work. Rotterdam-Ghent: NAi Publishers, Ludion, 2001.

Koldeweis, Jos, Paul Vandenbroeck i Bernard Vermet. Hieronymus Bosch. The Complete Paintings and Drawings. Rotterdam-Ghent: NAi Publishers-Ludion, 2001

Kren, Thomas i Scot McKendrick, red. Illuminating the Renaissance. The Triumph of Flemish Manuscript Painting in Europe. Los Angeles: Getty Publications, 2003.

LARSEn, Erik. Bosch. The Complete Paintings by the Visionary Master. New York: Smithmark, 1998.

LAwson, Colin i Robin Stowell, red. The Cambridge History of Musical Performance. Cambridge: Cambridge University Press, 2012.

Marijnissen, Roger H. i Peter Ruyffelaere. Hieronymus Bosch. Das vollständige Werk. Antwerpen: Mercatorfonds, 1999.

MAzo KARRAS, Ruth. Seksualność w średniowiecznej Europie. Tłumaczył Arkadiusz Bugaj. Warszawa: PIW, 2012.

McGeE, Timothy J. Medieval Instrumental Dances. Bloomington IN: Indiana University Press, 1990.

McGowan, Margaret M. Dance in the Renaissance. European Fashion, French Obsession. New Haven-London: Yale University Press, 2008.

McKinnon, James, red. Music in Early Christian Literature. Cambridge, New York: Cambridge University Press, 1987; repr. 1993.

Mirimonde, Albert P. de. „Le symbolisme musical chez Jérôme Bosch”. Gazette des Beaux-Arts 77(1971): 37-38.

Montagu, Jeremy. The World of Medieval and Renaissance Musical Instruments. Woodstock NY: Overlook Press, 1976; repr. 1980.

Mullally, Robert. The Carole. A Study of a Medieval Dance. Farnham, Burlington VT: Ashgate, 2011.

MunRow, David. Instruments of the Middle Ages and Renaissance. London: Oxford University Press, 1976.

NAKAS, Kassandra i Jessica UlLrich, red. Scenes of the Obscene. The Non-Representable in Art and Visual Culture, Middle Ages to Today. Weimar: VDG, 2014.

NEwhauSER, Richard, red. In the Garden of Evil. The Vices and Culture in the Middle Ages. Toronto: Pontifical Institute of Mediaeval Studies, 2005.

PleIJ, Herman. Het gilde van de Blauwe Schuit. Literatuur, volksfeest en burgermoraal in de late middeleeuwen. Amsterdam: Meulenhoff, 1983, wyd. 2.

PLEJ, Herman. Op belofte van profijt. Stadsliteratuur en burgermoraal in de Nederlandse letterkunde van de middeleeuwen. Amsterdam: Prometheus, 1991.

Ridderbos, Bernhard i Anne van Buren, Henk van Veen, red. Early Netherlandish Painting. Rediscovery, Reception, and Research. Amsterdam: Amsterdam University Press, 2005.

RoBERTS, Helene E., red. Encyclopedia of Comparative Iconography. Themes Depicted in Works of Art, t. 2. Chicago, London: Fitzroy Dearborn Publishers, 1998. 
SACHS, Curt. The History of Musical Instruments. London: J. M. Dent and Sons Ltd., 1942; repr. 1978.

SulzBERGER, Suzanne. „Jérôme Bosch et les maîtres de l'enluminure”. Scriptorium 16(1962): 46-49.

Schoute, Roger Van i Dominique Verboomen. Jérôme Bosch. Tournai: Renaissance du Livre, 2001.

Sigal, Gale. Erotic Dawn-Songs of the Middle Ages. Voicing the Lyric Lady. Gainesville FL: University Press of Florida, 1996.

Silva Maroto, Pilar, red. El Bosco. La exposición del V Centenario. Madrid: Museo Nacional del Prado, 2016.

SiLver, Larry. Hieronymus Bosch. New York: Abbeville Press, 2006.

SILVER, Larry. „Jheronimus Bosch and the Issue of Origins”. Journal of Historians of Netherlandish Art 1/1 (Summer)(2009). https://jhna.org. (dostęp: 12.05.2019).

SMEYERs, Maurits. Flemish Miniatures from the 8th to the mid-16th Century. The Medieval World on Parchment. Leuven: Davidsfonds, 1999.

SMIJERS, Albert. De Illustre lieve Vrouwe Broederschap te 's-Hertogenbosch. Amsterdam: b.d., 1932.

Augustyn, św. Wyznania. Tłumaczył Zygmunt Kubiak. Kraków: Znak, 1994, wyd. 5.

TRNEK, Renate. Das Weltgerichtstriptychon von Hieronymus Bosch in der Gemäldegalerie der Akademie der bildenden Künste in Wien. Rosenheim: Rosenheimer Verlagshaus, 1989.

VAndenBroeck, Paul. Jheronimus Bosch. De verlossing van de wereld. Ghent-Amsterdam: Ludion, 2002.

\section{LUXURIA, GRZECH I KARA. PRZYCZYNEK DO BADAŃ IKONOGRAFICZNYCH OŁTARZA SĄDU OSTATECZNEGO JHERONIMUSA BOSCHA (I JEGO WARSZTATU) Z AKADEMIE DER BILDENDEN KÜNSTE W WIEDNIU. CZĘŚĆ I}

\section{Streszczenie}

Oltarz Sąu Ostatecznego z Wiednia uważany jest obecnie przez członków Bosch Research and Conservation Project za dzieło Jheronimusa Boscha (ok. 1450-1516) i jego warsztatu. Reminiscencje oraz aluzje do grzechów nieczystości uobecniają się w Ottarzu wiedeńskim wielokrotnie. Choć w kilku scenach pojawiają się instrumenty muzyczne, często w sztuce łączone z miłością, to w literaturze przedmiotu aspekty muzyczne są często marginalizowane lub wręcz pomijane. Głównym celem niniejszego artykułu, oprócz analizy ikonograficznej owych kilku scen (część I), jest próba dotarcia do źródeł ideowych powiązania w wizji zaświatów dwóch elementów: kar odpowiadających jednemu z grzechów głównych (luxuria) z muzyką (część II). Umuzycznione sceny w Oltarzu Sądu Ostatecznego, wykazujące związki z malarstwem miniatorskim, przywołują na myśl realia historyczne - aspekty praktyki wykonawczej w ramach muzykowania prywatnego przełomu XV-XVI wieku.

Słowa kluczowe: Jheronimus Bosch; malarstwo niderlandzkie; Sąd Ostateczny; piekło; eschatologia chrześcijańska; nieczystość (luxuria); ikonografia muzyczna. 


\title{
LUXURIA, SIN AND PUNISHMENT. A PROLEGOMENON TO ICONOGRAPHIC RESEARCH OF THE LAST JUDGMENT BY JHERONIMUS BOSCH (AND HIS WORKSHOP) FROM AKADEMIE DER BILDENDEN KÜNSTE IN VIENNA. PART I
}

\begin{abstract}
Summary
The Last Judgement kept in Akademie der Bildenden Künste in Vienna is currently considered by members of the Bosch Research and Conservation Project as the work of Jheronimus Bosch (c. 1450-1516) and his workshop. Within the Vienna Triptych there are many reminiscences and allusions to unchastity, lasciviousness and lustfulness. Although musical instruments - often linked with love in visual arts - appear in several scenes, in the Bosch literature musical aspects are often marginalized or even overlooked. The main purpose of this article, apart from the iconographic analysis of these several scenes (part I), is an attempt to find sources of connection between two elements in the vision of Hell: penalties corresponding to the sin of lust (luxuria) with music (part II). The musical scenes in the Vienna Last Judgement having their origins in miniature painting, recall historical realities - aspects of private music making at the turn of the 15 th and 16 th centuries.
\end{abstract}

Key words: Jheronimus Bosch; early Netherlandish painting; Last Judgement; hell; Christian eschatology; lust (luxuria); musical iconography. 